\title{
GIH-Pobreziari aurre egiteko, oinarrizko errenta behar da
}

\author{
(Fighting poverty requires a basic income)
}

\author{
Angel Elias Ortega* \\ Zuzenbidean doktorea eta Lan Harreman eta Gizarte Langintza Fakultateko irakaslea
}

\begin{abstract}
LABURPENA: 2030eko Garapen Iraunkorrerako 1. Helburua, pobreziari aurre egiteari dagokiona, zer den gogorarazi ondoren, helburu horren egungo bilakaera eta zer neurritan betetzen den aztertu da, bai mundu mailan, bai Espainian eta Euskadin, eta bereziki aipatu dira langile pobreen kolektiboa eta gizarte-babeserako sistemak. Jarraian, ikusi da oinarrizko errenta unibertsala, baldintzarik gabea eta banakakoa eskatzea, pobreziaren atalasetik gorako zenbatekoa izango duena. Nazioarteko hainbat forotan aztertu eta planteatu den neurri bat da, bai Nazio Batuetan, bai Europako Kontseiluko Parlamentu Batzarrean, bai finantza- eta lan-munduko esparruetan. Espainian ere eskatu izan da, gizarte-lanaren, kulturaren eta osasunaren esparru profesionaletan, bai eta feminismoan, ekologismoan eta LGBTI kolektiboetan ere. Azkenik, ondorio eta gogoeta labur batzuk atera dira, non berresten baita iritsi dela unea oinarrizko errentak neurri utopikoaren kategoria alde batera utzi eta behingoz abian jartzeko, horrela pobrezia materiala desagerrarazi eta Garapen Iraunkorraren 1. Helburua bete dadin.
\end{abstract}

HITZ GAKOAK: Garapen iraunkorrerako helburua, pobrezia, aberastasunaren bidezko banaketa, oinarrizko errenta, eskubideak.

\begin{abstract}
After recalling what the first of the 2030 Sustainable Development Goals of combating poverty consists of, the evolution and current situation in the degree of its fulfilment is analysed, both at a global level and in Spain and the Basque Country, also making special reference to the group of poor workers and the social protection systems. Next, it is verified that the demand of an universal, unconditional and individual basic income, which has an amount superior to the threshold of poverty, is a measure that has been studied and also raised from different international forums, as much from the United Nations, as from the Parliamentary Assembly of the Council of Europe, or from scopes of the financial and labor world. In Spain it has also been demanded from spheres as different as the professional field of social work, culture and health, as well as from social movements such as feminism, ecology and LGBTI groups. Finally, some brief conclusions and reflections are drawn, where it is reaffirmed that the time has come for the Basic Income to abandon the category of utopian measure and become a reality, thus allowing for the eradication of material poverty and the fulfilment of the first of the Sustainable Development Goals.
\end{abstract}

KEYWORDS: Sustainable development goals, poverty, fair distribution of wealth, basic income, rights.

\footnotetext{
* Harremanetan jartzeko / Corresponding author: Angel Elias Ortega, UPV/EHU, Lan Harreman eta Gizarte Langintza Fakultatea, Sarriena auzoa, zk.g. (48940 Leioa, Bizkaia). - angel.elias@ehu.eus - https://orcid.org/0000-0002-7927-8835.

Nola aipatu / How to cite: Ortega, Angel Elias (2021). "GIH-Pobreziari aurre egiteko, oinarrizko errenta behar da»; Ekaia, ale berezia 2021, 15-30. (https://doi.org/10.1387/ekaia.22073).

Jasotze-data: 2020, urriak 20; Onartze-data: 2021, maiatzak 18

ISSN 0214-9001 - elSSN 2444-3255 / (c) 2021 UPV/EHU
}

(c) (i) $(-)$ Lan hau Creative Commons Aitortu-EzKomertziala-LanEratorririkGabe 4.0 Nazioartekoa

(c) 


\section{SARRERA}

2030eko Garapen Iraunkorrerako 1. Helburua (aurrerantzean, GIH) pobreziari aurre egitean datza, eta, Nazio Batuen ustez, beste helburu hauek dakartza berekin [1]:

1. Gaur egun eguneko 1,25 dolar baino gutxiagorekin bizi diren pertsonen muturreko pobrezia desagerraraztea mundu osoan.

2. Gutxienez erdira jaistea pobrezian bizi direnen proportzioa, dimentsio guztietan, definizio nazionalen arabera.

3. Gizarte-babeserako sistema eta neurri egokiak ezartzea estatu-mailan guztientzat, etxebizitza barne, eta pobreen eta kalteberen funtsezko estaldura lortzea.

4. Munduko herritar guztiek baliabide ekonomikoetarako eskubide berberak dituztela bermatzea, bai eta oinarrizko zerbitzuak, lurraren gaineko jabetza eta kontrola eta beste jabetza, herentzia, baliabide natural egoki batzuk, teknologia berria eta finantza-zerbitzuak eskuratzeko aukera ere, mikrofinantzak barne.

5. Berreskuratzeko gaitasuna garatzea eta klimarekin eta ekonomia-, gizarte- eta ingurumen-arloko beste shock eta hondamendi batzuekin lotutako muturreko gertaerekiko esposizioa eta kalteberatasuna murriztea.

2015. urtean, estatu gehienek GIHen konpromisoa hartu zutenean, laugarren industria-iraultzaren hastapenetan geunden. Iraultza horrek ezagutza eta baliabide teknologikoak ematen zituen, 2030. urtean «giza duintasunaren araberako existentzia» eskubidea izateko eta, horrenbestez, nazioarteko zenbait itunetan adierazitako giza eskubideak betetzeko. Adibidez, eskubide hauek: Giza Eskubideen Adierazpenaren (aurrerantzean, GEA [2]) 23. artikulua ( «Pertsona orok bere duintasunerako eta bere nortasunaren garapen askerako ezinbestekoak diren eskubideez gozatzeko duen eskubidea»), GEAren 22. artikulua («Bizi-maila egokirako eskubidea»), eta Eskubide Ekonomiko, Sozial eta Kulturalen Nazioarteko Itunaren [3] 11.1 artikulua («Pertsona orok eskubidea du berak eta beraren familiak bizi-maila egokia izateko, baita elikadura, jantzi eta etxebizitza egokiak ere, eta bizibaldintzak etengabe hobetzeko»). Gogoratu behar da itun horren eraginkortasuna bermatzeko ardura osoa estatu sinatzaileek hartu zutela beren gain, itunaren 2.1 artikuluak dioenaren arabera: «Neurriak hartzea, bai nork bere aldetik, bai nazioarteko laguntzaren eta lankidetzaren bidez, bereziki ekonomikoak eta teknikoak, gehienera arte, eskura dituen baliabideak, mailaz maila, bitarteko egoki guztiak erabiliz, legegintza-neurriak hartzea barne, hemen aitortutako eskubideen erabateko eraginkortasuna lortzeko». Ez da ahaztu behar gauza bera aitortzen zaiola haur orori Haurren Eskubideei buruzko Konbentzioaren [4] 27.1 artikuluan («Garapen fisiko, mental eta es- 
piritual, moral eta sozialerako bizi-maila egokirako eskubidea») eta estatu sinatzaileek hartutako konpromisoan, haien baldintza nazionalen eta bitartekoen arabera («Behar diren neurriak hartzeko, gurasoei eta haurren ardura duten beste pertsona batzuei laguntza emateko»). Eskubide horren eraginkortasuna eta, behar izanez gero, «laguntza materiala eta laguntzaprogramak ematea, bereziki nutrizioari, jantziei eta etxebizitzari dagokienez», Haurren Eskubideei buruzko Konbentzioaren 27.3 artikuluan ezarrita dago. Azkenik, Haurren Eskubideei buruzko Konbentzioaren 4. artikuluak ere jasotzen du neurriak hartzeko betebeharra, ahalik eta errekurtso gehien hartu arte, eskubide horiek eraginkorrak izan daitezen.

Jarraian, pobreziaren aurkako borrokaren egungo bilakaera eta egoera erakusten duten zenbait datu azalduko dira, eta, ondoren, oinarrizko errenta unibertsala, baldintzarik gabekoa eta banakakoa jorratuko da (aurrerantzean, OE), pobreziaren atalasearen baliokide den zenbatekoan, hori lortzeko beharrezko neurri gisa, eta, amaieran, ondorio eta gogoeta labur batzuk egingo dira.

\section{POBREZIAREN AURKAKO BORROKAREN BILAKAERA ETA EGUNGO EGOERA}

GIHetarako aurrerapenari buruz Nazio Batuen Erakundeko idazkari nagusiak egindako azken txostenaren datuen arabera [5], 2010ean \% 15,7 jaitsi ondoren, 2015ean, muturreko pobreziaren murrizketaren erritmoa are gehiago moteldu zen $(\%$ 10,0), eta, 2019an, \% 8,2ko tasara iritsi zen. COVID-19aren pandemiaren eraginak pobrezia murrizteko joera alderantzikatu du, eta aurreikusten da 2020an \% 8,4tik \% 8,8ra igoko dela munduko muturreko pobreziaren tasa. Horrek esan nahi du 2017ko mailara jaitsiko dela; izan ere, kalkulatzen da 40 eta 60 milioi pertsona artean itzuliko direla muturreko pobreziara, hau da, munduko pobreziaren lehen igoera 20 urtean baino gehiagoan.

Espainian ere egoera ez da ona, Nazio Batuen Erakundeko kontalariak 2020ko urtarrilaren 27tik otsailaren 7ra bitartean egindako bisitaren ondoren adierazi zuen bezala; izan ere, txostenaren laburpenaren lehen bi paragrafoetan, honako hau adierazi zuen: «Espainiako ekonomia, Europar Batasuneko laugarrena, etengabe hazi da krisiaz geroztik, eta langabeziak behera egitea eta soldatak eta esportazioak handitzea eragin du. Hala ere, susperraldiak gizartearen estratu aberatsenari egin dio mesede nagusiki, eta, neurri handi batean, botere publikoek huts egin diete pobrezian bizi diren pertsonei. Horren ondorioz, oraindik ere pobrezia handiko egoerak daude, langabezia-tasa handia, gazteen langabezia-egoera kronikoa, proportzio handiko etxebizitza-krisia, gizarte- babeserako programa oso eskasak, hezkuntza-sistema segregatua eta gero eta anakronikoagoa, 
klase egokituei behartsuei baino askoz gehiago laguntzen dieten zerga- eta gastu-politikak, eta agintariek erantzukizuna saihestu eta gehiago balioesten duten pentsamolde burokratikoa. Emakumeen ongizatearen arloan, begi-bistakoa da gizarte-laguntza emateko sistema hautsita dagoela, ez dela behar bezala finantzatzen, ezinezkoa dela bertan ez galtzea eta ez dela iristen behar handiena duten pertsonengana» [6]. Ondorio bera atera du Espainiako European Anti Poverty Network-ek (aurrerantzean, EAPN), zeren eta Espainian, 2020an, 3,3 milioi pertsonak gabezia material larria izan zuten; beraz, urtebetean, \% 4,7tik \% 7ra igo da proportzioa. Gainera, 9,94 milioi pertsona zeuden pobrezia eta/edo gizarte-bazterketa jasateko arriskuan, hau da, Espainiako biztanleen \% 21 [7]. Euskadin, 2018an, 109.735 pertsona zeuden pobrezia larriaren arriskuan, hau da, diru-sarreren medianaren $\%$ 40tik behera, eta beste 382.316 pertsona pobrezia erlatiboaren arriskuan zeuden, hau da, diru-sarreren medianaren \% 60tik behera [8].

Jarraian, bi adierazle garrantzitsuren egoera azalduko da.

\subsection{Langile pobreak}

Muturreko pobrezian bizi diren munduko langileen proportzioa $\%$ 14,3tik \% 8,3ra eta \% 7,1era jaitsi zen 2010., 2015. eta 2019. urteetan, hurrenez hurren. Saharaz hegoaldeko Afrikan, egoera kezkagarria da oraindik; izan ere, 2018an, langile pobreen proportzioa \% 38koa zen. Bestalde, aurrerapena ez zen hain pozgarria izan langile gazteentzat: 2019an, munduko langile gazteen $\%$ 12,8 muturreko pobrezian bizi ziren, langile helduen \% 6rekin alderatuta. Pandemia-egoera larriagotzen ari da, milioika langile langabeziara, azpienplegura eta lan-pobreziara bultzatu dituen heinean [5].

\subsection{Gizarte-babeserako sistemak zabaltzea}

Sistema horiek pobrezia prebenitzen eta murrizten laguntzen dute, eta pertsona kalteberentzako segurtasun-sare bat eskaintzen dute. Hala ere, munduko biztanleriaren gehiengo handi batek ez du babes sozialik: 2016an, biztanleen \% 55 (4.000 milioi pertsona) ez zeuden gizarte-babeserako eskudirutan lortutako irabaziez estalita, eta aldaketa handiak izan ziren eskualdeen artean: \% 87k ez zuten estaldurarik Saharaz hegoaldeko Afrikan, eta \% 14k, berriz, Europan eta Ipar Amerikan. Langabeen \% 22k soilik jaso zituzten irabaziak eskudirutan langabeziagatik; desgaitasun larriak zituzten pertsonen $\% 28 \mathrm{k}$ jaso zituzten irabaziak eskudirutan, desgaitasunagatik; haurren \% 35ek zuten gizarte-babeserako benetako sarbidea mundu osoan; eta erditu ziren emakumeen $\% 41 \mathrm{ek}$ jaso zituzten irabaziak eskudirutan, amatasunagatik. Herrialde guztien heren batek soilik gastatzen dute hezkuntzan guztizko gastu publikoaren $\% 15$ tik \% 20ra bitartean [9]. 
Latinoamerikan, 2020ko martxoaren 13tik apirilaren 24ra bitartean, 29 herrialdek babes sozialeko 126 neurri hartu zituzten etxe pobreenei, ahulenei eta prekarizatuenei pandemiari aurre egiten laguntzeko. Neurri nagusiak elikagaiak entregatzea eta diru-transferentzia berriak sortzea izan ziren (hartutako neurri guztien \% 33 eta $\% 27$, hurrenez hurren). Neurri horien ondoren, sarritan, oinarrizko zerbitzuen (ura, energia, telefonoa eta Internet) ordainketa etetea eta diru-transferentzien zenbatekoa handitzea lehenetsi zen (\% 19 eta \% 13, hurrenez hurren). Azkenik, transferentziaprogramak entregatzeko aurrerakina neurri guztien $\% 5$ izan zen, eta dirutransferentzien biztanleria-estaldura \% 4 handitu zen [10].

Aurreko egoera Nazio Batuen Kontseilu Ekonomiko eta Sozialak 2020ko uztailaren amaieran deitutako Ministerio Adierazpenak ere sinatu zuen, eta laugarren puntuan zera berretsi zuen: «Pobrezia bere forma eta dimentsio guztietan desagerraraztea, muturreko pobrezia barne, munduko erronkarik handiena eta garapen iraunkorrerako ezinbesteko baldintza da, eta kontuz ikusten da, lehen aldiz, joera alderantzikatzen ari dela hamarkada batzuetan, eta pobrezia murrizten ari dela». Era berean, GIHak betetzeko konpromisoa berretsi zuen, baina hori lortzeko ekintzen zerrendan zehaztasuna eta neurri berriak falta ziren [11].

\section{OINARRIZKO ERRENTA UNIBERTSALA, BALDINTZARIK GABEKOA ETA BANAKAKOA ESKATZEA}

OEaren kontzeptua bera eraginkorra da pobreziaren aurkako borrokan, eta, 2007an, Monterreyko Giza Eskubide Sortzaileen Adierazpen Unibertsalean [12] sartu zen, zehazki 1.3. atalean. Honela dio: «Oinarrizko errenta edo herritarren diru-sarrera unibertsalerako eskubidea, pertsona orori, adina, sexua, sexu-orientazioa, egoera zibila edo lan-egoera edozein izanik ere, duintasun-baldintza materialetan bizitzeko eskubidea bermatzeko. Horretarako, zerga-erreformen bidez eta estatuko aurrekontuen kontura ordaindutako aldizkako diru-sarrera baldintzarik gabe jasotzeko eskubidea aitortzen zaio, herritartasun-eskubide gisa, gizarteko kide egoiliar bakoitzari, beste errenta-iturriak alde batera utzita, egokia izan dadin haren oinarrizko beharrak betetzeko».

Oinarrizko errenta unibertsala, baldintzarik gabekoa eta banakakoa aztertzea eta eskatzea, pobreziaren atalasearen baliokide den zenbatekoan, oso gertakari esanguratsua da azken bost urteotan eta, bereziki, 2020. urtetik, COVID-19aren pandemiaren ondorioz. Horren protagonista nagusiak esparru akademikoa eta gizarte-mugimenduak izan dira, nahiz eta OEaren nazioarteko erreferentzia Basic Income Earth Network (aurrerantzean, BIEN) sarea izan joan den mendearen amaieratik [13]. Gaur egun, OEaren eta COVID-19aren pandemiaren arteko harremanari buruzko eztabaidak garatzen ari da BIEN mundu osoan; dagoeneko, hiru daramatza. 
Segidan, nazioarteko planoa aztertuko da, eta, ondoren, Espainiakoa.

\subsection{Nazioartean}

\subsubsection{Nazio Batuen eremuan}

Nazio Batuen Garapen Iraunkorrerako Helburuen 2018ko Txostenak, Panorama Orokorrean 1. GIHa aipatzean, honako hau zioen: «Pobreziari amaiera emateko, pertsona guztiak beren bizitzaren ziklo osoan babesteko gizarte-babeserako sistema unibertsalak behar dira» [14]. Duela gutxi, Nazio Batuen Garapenerako Programaren bidez, COVID-19aren aurkako aldi baterako oinarrizko errenta unibertsala proposatu zuen [15]. Era berean, Latinoamerikako eta Karibeko Batzorde Ekonomikoak honako hau adierazi zuen 2020ko maiatzaren 12ko prentsa-oharrean: «Pandemiak larriagotu dituen eten historiko handien aurrean, eskubideen ikuspegitik politika unibertsal, birbanatzaile eta solidarioak ezartzeko unea da» [16]. Hain zuzen ere, egun horretan argitaratutako txostenean, beharrak asetzeko eta kontsumoari eusteko oinarrizko diru-sarrera unibertsal bat proposatzen zen, eta kalkulatu zen oinarrizko diru-sarrera unibertsal horren urtebeteko kostua BPGaren \% 18,4koa dela, egungo transferentzia baldintzatuen \% 1,22ren aldean. Kalkulua egiteko, Latinoamerikako 18 herrialde hartu ziren erreferentziatzat, zehazki: Argentina, Bolivia, Brasil, Txile, Kolonbia, Costa Rica, Ekuador, El Salvador, Guatemala, Honduras, Mexiko, Nikaragua, Panama, Paraguai, Peru, Dominikar Errepublika, Uruguai eta Venezuela [10].

Joan den 2020ko uztailaren 17an, Kanni Wignaraja Nazio Batuetako Asiako eta Ozeano Bareko Garapenerako Programaren eskualdeko zuzendariordeak oinarrizko errenta unibertsala martxan jartzeko beharra nabarmendu zuen. Ordaindu ezin diren defizit jasanezinak sortzen dituela argudiatzen dutenen aurrean, planteatu zuen alternatibak desberdintasuna areagotzea ekarriko duela, eta horrek gizarte-tentsioak areagotuko lituzkeela, gobernuei kostu handiagoa ekarriko liekeela eta herrialdeei gatazka zibila izateko arrisku handiagoa eragingo liekeela. Zerga-karga justua behar dela esan zuen, eta herrialdeek elkarrekin lan egin beharko dutela eta datuak trukatu beharko dituztela, pertsonek eta enpresek zergak saihestu ez ditzaten. Credit Suisse finantza-zerbitzuen enpresak 2018ko aberastasun globalari buruz egindako txostenaren arabera, munduko pertsona aberatsenen \% 10ek aberastasunaren \% 85 dute. Jada ezin ditugu irabaziak pribatizatu eta galerak sozializatu, eta, planeta osoko lehen mila korporazioek zerga kopuru justua ordainduko balute, mundu osoan oinarrizko errenta unibertsal xume bat banatzea ahalbidetuko litzatekeela gaineratu zuen. Erregai fosilentzako dirulaguntzak bukatzea ere defendatu zuen, GIHei laguntzea eta baliabide ekonomiko gehiago sortzea ahalbidetuko bailuke. Amaitzeko, honako hau esan zuen: «Oinarrizko errenta unibertsala ez izatearen alternatiba da istilu sozialak, gatazkak, migrazio masibo kontrolae- 
zinak gertatzeko probabilitatea handitzea eta frustrazio soziala aprobetxatzen eta astintzen duten muturreko taldeak ugaritzea. Testuinguru horretan, serioski hartu behar dugu kontuan ondo diseinatutako oinarrizko errenta unibertsala aplikatzeko aukera, krisiek jo ahal izan dezaten, baina ez suntsitu» [17].

\subsubsection{Europako Kontseiluaren esparruan}

2018ko urtarrilaren 23an, Europako Kontseiluko Parlamentu Batzarrak ebazpen bat onartu zuen, non, beste akordio batzuekin batera, 47 estatu kideak oinarrizko errenta unibertsalak eskubideak eta gizarte-kohesioa lortzeko bidean aurrera egitea ahalbidetzen duten jarduerak sustatzera animatzen zituen [18]. Zehazki, Gizarte Gaietarako, Osasunerako eta Garapen Jasangarrirako Batzordearen txostenean, Nunzia Catalfo andrea kontalari zela, honako hau zioen: «Pobreziarekin eta giza duintasuna etengabe ahultzen duten desberdintasunen igoerarekin, Europako herrialde gehienak guztiontzako bizi-maila egokia bermatzeko borrokan ari dira. Oinarrizko diru-sarrera edo herritartasunekoa gizarte-segurantzako modu bat da, herritar bakoitzari bizitzeko diru kopuru erregular bat eman diezaiokeena. Unibertsaltzat, banakakotzat, baldintzarik gabekotzat eta bizitza duina eta gizartean parte hartzea bermatzeko nahikotzat definituta, erabateko pobrezia arintzen lagunduko luke, eta, aldi berean, lan egiteko pizgarriak kenduko lituzke. Lan ez-estandarrean lan egiten duten eta lana partekatzen duten pertsonen eta azpienplegatuen diru-sarrerak osa ditzake. Oinarrizko diru sarrera bat sartzeak guztientzako aukera-berdintasuna bermatu ahal izango luke, gizarte-prestazio, -zerbitzu eta -programen mosaikoa baino modu eraginkorragoan. Hala ere, gizarte-politika hain goitik behera aldatzeko zailtasun praktikoak direla eta, herrialde bakoitzean sakoneko eztabaida egin behar da etengabe bermatutako diru-sarrera horren modalitateak zehazteko eta herritarren eta estatuaren arteko gizarte-kontratu berri baten parte gisa finantzatzeko moduak zehazteko. Ondorioz, txostenean, estatu kideei gomendio batzuk egiten zaizkie, eta iraganean eta orain egindako ekimenak aztertzera gonbidatzen dira, hau da, maila guztietako oinarrizko diru-sarrerak bertatik bertara frogatzera eta biztanleriaren kategoria kalteberei ematen zaien laguntza handitzera» [19].

\subsubsection{Finantza-arloan}

Munduko Ekonomia Foroak ikerketa bat argitaratu zuen, 2016an, eta, bertan, OEak dituen ahalmenak aztertu zituen [20].

Nazioarteko Diru Funtsak, 2017an argitaratutako Fiscal Monitor txostenean, zerga-politikek birbanatze-helburuak lortzeko egin dezaketen ekarpena aztertu zuen, funtsezko hiru eztabaidatan oinarrituta. Hain zuzen, haietako bat OEa onartzea zen [21]. 
Munduko Bankuak, 2020. urtearen hasieran, OEari buruzko azterlan bat argitaratu zuen, horri buruz pentsatzeko esparru edo gida bat eskaini nahian, bereziki diru-sarrera txiki eta ertainak dituzten herrialdeetako testuinguruetara zuzenduta [22].

\subsubsection{Lan-arloan}

2018an, Lanaren Nazioarteko Erakundeak gobernuei proposatu zien arretaz hausnartu behar zutela OEa Gizarte Babeseko Sisteman txertatzeko modu eraginkor bati buruz, ondo pentsatutako gizarte-aseguru publiko batekin eta gizarte-babeseko beste prestazio batzuekin konbinatuta, bai eta kalitate handiko zerbitzu publikoetarako benetako sarbidea bermatzeko neurri eraginkorrei buruz ere, hala nola osasuna, hezkuntza, arreta eta beste gizarte-zerbitzu batzuk [23].

Era berean, Nazioarteko Konfederazio Sindikalak, 2018ko txosten batean, babes sozial integraleko sistema egokien garapena babestu zuen, OEa barne [24].

\subsection{Espainiako estatuan}

Atal honetan, COVID-19aren pandemiatik eratorritako krisiari aurre egiteko neurriak eskatzen diren azken etapa honetan jarriko da arreta. Horretarako, Espainiako Gobernuak onartutako bizitzeko gutxieneko diru-sarrerak (aurrerantzean, BGDS) sortu dituen erreakzioak azalduko dira; lehenik, gizarte-lanaren, kulturaren eta osasunaren esparruetan, baina, ondoren, baita hainbat gizarte-mugimenduren ikuspegitik ere.

\subsubsection{Gizarte-lanaren esparruan}

Espainiako Gizarte Laneko Kontseilu Nagusiak berriki onartutako berme-errentei buruzko txostenak, Espainian Gizarte Laneko elkargo profesional guztiak biltzen dituenak, aipatu zuen BGDSa premiazkoa dela une honetako babesgabetasun larriko egoera arintzeko. Baina, aldi berean, argi eta garbi aldeztu zuen ez dela COVID-19ak eragindako osasun-larrialdira mugatu behar; izan ere, diru-sarrerak bermatzeko sistema bat sortu behar da herritarren eskubide gisa, eta programarik onena OEa da [25].

Era berean, Espainian, gizarte- eta hezkuntza-arloko 650 profesionalek OE baten aldeko manifestua sinatu zuten, 2020ko ekainean, pertsonen bizitza material duinerako eskubidea bermatzeko ezinbesteko eta beharrezko politika dela sinetsita. Manifestua amaitzeko, honako hau esan zuten: «Azken batean, OEak politika publiko bat egitea dakar, bizitzeko eskubidea eta gutxieneko bizi-materialak bermatzeko. Politika horrek, aldi berean, aukera asko irekitzen ditu bizitzako beste dimentsio batzuetan, non gizarte- eta hezkuntza-arloko esku-hartzearen profesionalok jarduten dugun» [26]. 
Gizarte Ekintzako Erakundeen Kataluniako Federazioak ere, bazterkeria-egoeran edo arriskuan dauden pertsonekin lan egiten duten 114 erakunde biltzen dituenak, kritikatu zuen eskakizunen konplexutasuna, burokrazia eta BGDSa izapidetzen laguntzeko baliabide gutxi izatea, pobreziatik ateratzea ahalbidetzen ez duen prestazio oso urria eskuratzeko bideak gainditzen baitituzte. Kudeaketa sinplifikatu eta egoera ahulean dauden pertsonen estigmatizazioa apurtuko duen OE baterantz aurrera egitea eskatu zuen, eta horrek nahitaez fiskalitatea berrikustea dakar, hura finantzatzeko baliabideak lortzeko [27].

Azkenik, adierazgarria izan zen 2020ko ekainaren 22an Espainiako Diputatuen Kongresuko Berreraikuntza Ekonomiko eta Sozialeko Batzordean agertu izana, aditu ekonomista gisa, unibertsitateko irakasle eta Oinarrizko Errenta Sareko presidentea den Daniel Raventos Panyella, zeinak modu distiratsu eta oso arrazoituan kritikatu baitzituen pobreziari eraginkortasunez aurre egiteko neurri gisa baldintzatutako berme-errentak, eta OEa ezartzea eskatu [28]. Urte bat geroago, Kataluniako Gobernuak Plan Pilotuaren Bulegoa sortu du oinarrizko errenta unibertsala ezartzeko, eta Danielen anaia den Sergi Raventós Panyella jauna izendatu du haren buru, 2021 eko irailaren 10eko Kataluniako Generalitatearen Aldizkari Ofizialean (8499. zk.) argitaratu zen bezala.

Hain zuzen ere, Daniel Raventosek, beste akademiko ospetsu batzuekin batera [29], Espainiako OEa zentzuz eta era bidezko batean finantzatzeko proposamen bat argitaratu zuen. Proposamen horren arabera, 18 urtetik gorako edozein herritar edo egoiliar akreditatua urtean 7.471 euroko $\mathrm{OE}$ batek eta adin horretara iristen ez denarentzat urtean 1.494 eurokoa izateak pobrezia desagerraraziko luke, eta egungo PFEZaren erreforma sakon baten bidez finantzatu ahalko litzateke, estatutik egungo diru-sarrerarik kendu beharrik gabe. PFEZetik, baina beste diru-prestazio publiko guztiak ordezkatuz: sorospenak, bekak, pentsioak, etab. Duela gutxi, autore berek proposatu zuten nola finantza zitezkeen, zenbateko desberdinen arabera, Espainiako gutxieneko diru-sarrera unibertsal eta baldintzarik gabekoak. Hala, Espainia osorako batez besteko pobreziaren atalasearen erreferentziarekin, 8.815 euroko OEa ateratzen zen urtean; PFEZ berriaren tasa bakarra \% 46,83 izango litzateke, eta Giniren indizea 15 puntu inguru murriztuko litzateke. Pobrezia eta pobrezia larria jasateko arriskuan dauden familien ehunekoak ia behera egingo luke: \% 0,54 eta \% 0,15 izango lirateke pobreak, bizi-baldintzen inkestan adierazitako \% 19,28 eta \% 8,46ren aldean. Birbanatze-efektua \% 14,78koa litzateke, eta, aurreko egoeran, berriz, \% 3,8koa [30]. Baina oraindik gehiago merkatuko litzateke OEaren zenbatekoak Espainiako etxebizitzen prezioen arteko desberdintasuna kontuan hartuko balu, eta, beraz, kostu osoa BPGaren \% 3,81era iritsiko litzateke [31]. 


\subsubsection{Kulturaren arloan}

2020. urtean, kultura-sektoreko mila profesionalek baino gehiagok manifestu bat sinatu zuten, OEa defendatzeko, denik eta kultura politikarik onena balitz bezala. Ziotenez, OE batek autonomia handiagoa, erabakitzeko askatasun handiagoa eta negoziatzeko gaitasun handiagoa ekarriko luke kultura-sektorean eta beste sektore batzuetan. Halaber, adierazi zuten OEa ez dela panazea bat eta beste neurri batzuekin batera funtzionatu behar duela, eta inola ere ez dela horretaz baliatu behar beste baliabide sozial batzuk ezabatzeko. Laburbilduz, uste zuten OE bat ezarri behar dela arrazoi honengatik: «Kulturarentzat onuragarria iruditzen zaigu oinarrizko errenta unibertsala, beharra duten pertsonak zuzenki laguntzen dituelako, eta ez delako estrukturetan galtzen, beste hainbat finantziazio sistema publikotan gertatzen den bezala, teorikoki goitik behera doan aberastasun emarian galtzen direnak eta sekulan behera ailegatzen ez direnak. Hainbatetan ezberdintasunak handitzea baizik ez dute lortzen eta gutxien behar dutenak bihurtzen dira onuradun.» [32].

\subsubsection{Osasun-arloan}

2021. urtean, ospe handiko 44 euskal ikertzailek COVID-19aren Liburu Zuria idatzi zuten, eta, 49. orrialdean, atal sozioekonomikoaren barruan, honako proposamen hau jasotzen da: «Pandemia-garaian Oinarrizko Errenta Unibertsala ezartzeko behar diren mekanismoak aztertzea. Oinarrizko errenta unibertsalaren ereduaren arabera, gaur egungo errentak bermatzeko sistemek estaldura unibertsaleko eta baldintzarik gabeko sistemaren norabidean aurrera egiteko aukerei buruzko elkarrizketa publiko zabal bat irekitzea eta bultzatzea» [33].

\subsubsection{Hainbat gizarte-mugimenduren esparruan}

\subsubsection{Feminismoa}

2020. urtean, erakunde eta pertsona askok manifestu feminista bat sinatu zuten OEaren alde, eskubide eta zerbitzu publikoen defentsarekin eta hedapenarekin zerikusia duela ulertuta: osasunarekin, hezkuntzarekin, zaintzarekin eta garatzeke daudenekin lotutakoak, hala nola etxebizitzarekin lotutakoa. Ziotenez, «zerbitzu horiek uzkurtu edo okertzen direnean, ondorioa gure sorbaldetan lan gehiago egitea eta gure izakinetan ziurgabetasun handiagoa izatea da». Era berean, «baldintzarik gabe baliabideak edukitzeak libratu egingo gintuzke paternalismo burokratikoaren eta indarkeria instituzionalaren eraginpean jarri behar izatetik, bizitzarako oinarrizkoa dena lortzeko, lan merkatuak baztertzen edo gaizki tratatzen gaituenean. OEa, azken batean, tresna erreala izango litzateke, indarkeriaren aurrean ukigarria» [34]. 


\subsubsection{Ekologismoa}

2020. urtean, Akademiako profesional talde batek, arlo akademikoko, unibertsitateko eta ikerketa-zentroetako 764 ikertzaile eta irakaslek, beste 3.213 pertsonak eta 191 euskal erakundek, tartean ELA, LAB, ESK eta STEILAS sindikatuek, edo EH Bildu eta Elkarrekin Podemos koalizioek, Euskal Herriko Ekonomia Ekologikoaren aldeko Manifestua sinatu zuten. Eztabaida eta prozesu sozial eta estrategiko horren bidez, trantsiziorako aukera eta proposamen zehatzak landu zituzten, ekonomia ekologikoan oinarrituta, etorkizuneko erronkei erantzun jasangarriak eta bidezkoak emateko. Eraldaketa hori bultzatzeko, lehentasunezko bost jarduera-ildo planteatu ziren, eta horiek zehazten eta aplikatzen hasi beharko lirateke, atzerapenik gabe, osasun-krisia desagertu ondoren garatzen jarraitzeko. Eta, zehazki, bigarren jarduera-ildoan, honako hau adierazi zuten: «Erakunde publikoetatik, ekoizpen, kontsumo eta inbertsio politikak sustatzea, muga ekologikoak kontuan hartuko dituztenak eta etorkizuneko belaunaldientzat bidegabea eta onartezina den zor bat sortzea saihestuko dutenak. Era berean, oinarrizko errenta unibertsala ezartzearen esparruan, zaintza sistema bat garatu behar da, non pertsonak zentroan egongo diren, gure ahultasuna eta interdependentzia aitortuz» [35].

\subsubsection{LGBTI kolektiboak}

2020ko ekainaren 25ean, LGBTI kolektiboek manifestu bat onartu zuten, OE baten bidez izateko eta existitzeko eskubidea zutela baieztatuz. Emantzipatu ezin direnez errespetatuak ez diren etxe batean bizi behar duten gazteen egoera salatu zuten, baita familia LGBTIfobikoekin konfinamendua igaro zutenena eta BGDSa eta halako neurrietatik kanpo dauden LGBTI adingabeena ere. OEa eskatu zuten «oinarrizko beharrak aseak izatea bermatzeko. Gureak ez ezik, herritar guztienak ere bai, emakumeentzat, adingabeentzat eta gizarte-kolektiboentzat bereziki eskuragarri bihurtzeko». Mugimendu feministako kideek genero-ikuspegi garbiarekin jokatzea aldarrikatu zuten, horrek bermatuko baitu bizitzari eusteko beharrezkoa dena, horrek emango baitigu gure bizitzak egiten jarraitu ahal izateko denbora, eta banakakoa, unibertsala eta baldintzarik gabea izan behar du. Neurri hori premiaz inplementatuz gero, sabaia eta elikagaia bermatzeaz gain, lan-diskriminazio LGBTIfobikoko egoerekin amaitzeko aukera ere bermatuko liguke, baita familia-eremuko edo bikote barruko indarkeria-egoeretatik irteteko aukera ere, eta gehiegikeriazko lan-baldintza prekario edo iraingarriak jasan beharrik ez izatea, ekonomikoki eta sozialki kaleratzeko edo baztertzeko beldurrez. Ez dago harrotasunik ustiatuta bagaude» [36]. 


\section{ONDORIOAK ETA GOGOETAK}

COVID-19aren pandemiak 1. GIHa betetzea urrundu du. Hala ere, gogoratu behar da giza eskubideen arloko legeria betetzeko estatuek eskura dituzten baliabide ekonomiko guztiak erabili behar dituztela bizimodu duina eta, beraz, pobreziarik gabea bermatzeko.

Horretarako, aberastasuna modu bidezko batean banatzeko politika bat behar da. Agindu etiko eta legezko bat da, eta gizarte-sektore asko eskatzen ari dira. Espainiaren kasuan, zergen eta transferentzien sistemak birbanatze-ahalmen txikia du, korrelazio esanguratsua baitago desberdintasun handiaren (\% 34 Gini koefizientea) eta diru-bilketa publikoaren maila txikiaren (BPGaren \% 36, EB-15eko txikiena, Irlandan izan ezik) artean.

Aurrekoetan argitaratu den bezala, OEak, pobreziari aurre egiteaz eta haren biktimak ez estigmatizatzeaz gain, baditu beste hainbat birtualtasun, justizia sozialetik, aberastasunaren birbanaketatik eta askatasunetik hasita, baina baita beste hainbat esparrutan ere, hala nola lanean, genero-berdintasunean, demokrazian eta herritarren parte-hartzean, gazterian eta administrazioaren eraginkortasunean [37]. Horrela, OEa erabat lerrokatuta dago Nazio Batuen 2030eko GIHak betetzearekin, 2030 Ekintza Plataformak egiaztatzen duen bezala, Hamazazpi: Garapen Iraunkorrerako Helburuetarako Diziplinarteko Ikerketa aldizkariaren 1. zenbakia eskaini baitiote neurri horri soilik [38].

OEak aldaketa kultural sakonak eskatzen ditu, eta horietako bat, hain zuzen ere, inbertsio gisa eta ez gastu gisa ulertzea da. Osasunean edo hezkuntzan inbertitzen denean, ez da zalantzan jartzen egindako «gastua» (are gutxiago pandemiak erakutsi duenean zer garrantzi duten inbertsio horiek), eta, hala ere, oinarrizko errentaz ari garenean, galdetzen den lehenengo gauza hau da: «Eta zenbat kostatuko litzaiguke?». Galdera aldatzeko eta inbertsioaz hitz egiteko unea da. Inbertsio horrek gure bizitzako alderdi askori eragingo lioke, eta, ikuspuntu ekonomikotik, ez da lurruntzen den gastu bat, banatzen den aberastasunaren zati bat baizik, eta, ondorioz, herritar bakoitzaren eta komunitatearen beraren zeregina indartuko litzateke.

Hori guztia dela eta, garaia iritsi da, Rutger Bregmanek [39] eta Martin Lagok [40] eskatzen zuten bezala, OEa neurri utopikoaren kategoria alde batera uzteko, eta Espainiako Gobernuan dagoen egungo alderdiak gara dezala Pedro Sánchez idazkari nagusia buru izan zuen hautagai-zerrendaren hauteskunde-programaren 85. atalean jasotakoa: «OE batekin lotutako formula bideragarrien egokitasuna balioestea» [41]. Halaber, mundu-mailan, baztertuek soldata unibertsala jaso dezatela, Frantzisko Aita Santuak 2020an eskatutakoa betez [42]. Horrela ulertu dute Europar Batasuneko [43] eta Euskal Autonomia Erkidegoko hainbeste herritar [44] Baldintzarik Gabeko Oinarrizko Errentaren aldeko Legegintzako Herri 
Ekimenak bultzatzean, jakinik OEa beharrezkoa dela pobrezia materiala desagerrarazteko eta 2030erako 1. GIHa betetzeko.

\section{BIBLIOGRAFIA}

[1] 2030eko GARAPEN IRAUNKORRERAKO HELBURUAK: 1. GIHa, 2015. https://www.un.org/sustainabledevelopment/es/poverty/ (eguneratzedata: 2021/09/29).

[2] UNIVERSAL DECLARATION OF HUMAN RIGHTS. 1948. https:// www.un.org/en/universal-declaration-human-rights/ (eguneratze-data: 2021/09/29).

[3] INTERNATIONAL COVENANT ON ECONOMIC, SOCIAL AND CULTURAL RIGHTS. 1966. https://www.ohchr.org/en/professionalinterest/pages/ cescr.aspx (eguneratze-data: 2021/09/29).

[4] CONVENTION ON THE RIGHTS OF THE CHILD. 1989. https:// www.ohchr.org/en/professionalinterest/pages/crc.aspx (eguneratze-data: 2021/09/29).

[5] UNITED NATIONS. ECONOMIC AND SOCIAL COUNCIL. 2020. Progress towards the Sustainable Development Goals Report of the SecretaryGeneral. https://undocs.org/en/E/2020/57 (eguneratze-data: 2021/09/29).

[6] HUMAN RIGHT COUNCIL. 2020. Report of the Special Rapporteur on extreme poverty and human rights on his visit to Spain. General Assembly of United Nations. https://undocs.org/en/A/HRC/44/40/Add.2 (eguneratzedata: 2021/09/29).

[7] EAPN. 2021. Pobreziaren estatuaren emaitzen aurrerapena. https://www. eapn.es/estadodepobreza/ARCHIVO/documentos/Informe_AROPE_2021_ Avance_resultados_julio.pdf (eguneratze-data: 2021/09/29).

[8] EUSKO JAURLARITZA. 2019. Desberdintasunari buruzko txostena. Emaitza nagusiak. Gizarte Beharrei buruzko Inkesta 2018. PGDI Pobrezia modulua. Eusko Jaurlaritzako Enplegu eta Gizarte Politiketako Sailaren Estatistika Organo Espezifikoa, Vitoria-Gasteiz.

[9] UNITED NATIONS. ECONOMIC AND SOCIAL COUNCIL. 2019. Special edition: progress towards the Sustainable Development Goals Report of the Secretary-General. United Nations, New York. https://undocs.org/ E/2019/68 (eguneratze-data: 2021/09/29).

[10] LATINOAMERIKAKO ETA KARIBEKO BATZORDE EKONOMIKOAK. 2020. Erronka soziala Covid-19aren garaian, United Nations, New York. https://www.cepal.org/es/publicaciones/45527-desafio-socialtiempos-covid-19 (eguneratze-data: 2021/09/29).

[11] UNITED NATIONS. ECONOMIC AND SOCIAL COUNCIL. 2020. Ministerial declaration of the high-level segment of the 2020 session of the Economic and Social Council and the 2020 high-level political forum on sustainable development, convened under the auspices of the Council, on the theme 
"Accelerated action and transformative pathways: realizing the decade of action and delivery for sustainable development», United Nations, New York. https://sustainabledevelopment.un.org/content/documents/26780MD_2020_ HLPF_HLS.pdf (eguneratze-data: 2021/09/29).

[12] UNIVERSAL DECLARATION OF EMERGING HUMAN RIGHTS. 2007. https://www2.world-governance.org/IMG/pdf_DUDHE.pdf (eguneratzedata: 2021/09/29).

[13] BASIC INCOME EARTH NETWORK. https://basicincome.org/about-basic-income/ (eguneratze-data: 2021/09/29).

[14] UNITED NATIONS. 2019. The Sustainable Development Goals Report 2018. United Nations, New York. https://unstats.un.org/sdgs/files/ report/2018/TheSustainableDevelopmentGoalsReport2018-EN.pdf (eguneratze-data: 2021/09/29).

15] GRAY MOLINA GEORGE, ORTIZ-JUAREZ EDUARDO. 2020. Temporary Basic Income, Protecting Poor and Vulnerable People in Developing Countries. United Nations Development Programme, New York. https:// www.undp.org/content/dam/undp/library/km-qap/Temporary $\% 20 \mathrm{Basic} \% 20$ Income-V4.pdf (eguneratze-data: 2021/09/29).

[16] LATINOAMERIKAKO ETA KARIBEKO BATZORDE EKONOMIKOAK. 2020. Prentsa-oharra, maiatzaren 12koa. https://www .cepal. org/es/comunicados/cepal-propone-avanzar-un-ingreso-basico-ayudar-lapoblacion-mas-vulnerable-superar (eguneratze-data: 2021/09/29).

[17] WIGNARAJA KANNI. 2020. United Nations, New York https://news. un.org/es/story/2020/07/1477601 (eguneratze-data: 2021/09/29).

[18] PARLIAMENTARY ASSEMBLY OF THE COUNCIL OF EUROPE. 2018. The case for a basic citizenship income. Resolution of 23 January. Brusela. http://assembly.coe.int/nw/xml/Votes/DB-VotesResults-EN. asp? VoteID=36977\&DocID=16468\&MemberID= (eguneratze-data : 2021/09/29).

[19] COMMITTEE ON SOCIAL AFFAIRS, HEALTH AND SUSTAINABLE DEVELOPMENT. PARLIAMENTARY ASSEMBLY OF THE COUNCIL OF EUROPE. 2018. Amendment about The case for a basic citizenship income. Brusela http://assembly.coe.int/nw/xml/XRef/Xref-XML2HTML-en. asp?fileid=24285\&lang=en (eguneratze-data: $2021 / 09 / 29$ ).

[20] WORLD ECONOMIC FORUM. 2016. The Future of Jobs. Employment, Skills and Workforce Strategy for the Fourth Industrial Revolution. Cologny. http://www3.weforum.org/docs/WEF_Future_of_Jobs.pdf (eguneratze-data: 2021/09/29).

[21] INTERNATIONAL MONETARY FUND. 2017. «Tackling Inequality», Fiscal Monitor, October. https://www.imf.org/en/Publications/ FM/Issues/2017/10/05/fiscal-monitor-october-2017 (eguneratze-data: 2021/09/29).

[22] GENTILINI, U., GROSH, M., RIGOLINI, J., YEMTSOV, R. 2020. Exploring Universal Basic Income: A Guide to Navigating Concepts, Evidence, 
and Practices. World Bank, Washington. https://openknowledge.worldbank. org/handle/10986/32677 (eguneratze-data: 2021/09/29).

[23] ORTIZ, I., BEHRENDT, C., ACUÑA-ULATE, A. eta NGUYEN, Q. 2018. «Universal Basic Income proposals in light of ILO standards: Key issues and global costing». ILO. Extension of Social Security. Working Paper, 62, 26-30. https://www.ilo.org/wcmsp5/groups/public/---ed_ protect/---soc_sec/documents/publication/wcms_648602.pdf (eguneratzedata: 2021/09/29).

[24] NAZIOARTEKO SINDIKATU-KONFEDERAZIOA. 2018. Politika ekonomiko eta sozialari buruzko txostena: oinarrizko Errenta Unibertsala. https:// www.ituc-csi.org/IMG/pdf/universal_basic_income_es.pdf (eguneratzedata: 2021/09/29).

[25] ESPAINIAKO GIZARTE LANEKO KONTSEILU NAGUSIA. 2020. Gizarte Lana Errenta Bermearen aurrean. Madril. http://www.cgtrabajosocial.es/app/webroot/files/consejo/files/emergencias/Trabajo\%20social\%20 Garanti\%C3\%ACa\%20de\%20Rentas\%2021.05.2020\%20(1).pdf (eguneratze-data: 2021/09/29).

[26] GIZARTE ETA HEZKUNTZA ARLOKO ESKU HARTZEKO PROFESIONALAK. 2020. Oinarrizko errenta unibertsal baten aldeko manifestua. http://www.rendabasicaara.org/ (eguneratze-data:2021/09/29).

[27] GIZARTE EKINTZAKO ERAKUNDEEN KATALUNIAKO FEDERAZIOAK. 2020. Zergatik bizitzako gutxieneko diru sarrera bat oinarrizko errenta unibertsal bat dagoenean?. https://acciosocial.us15.list-manage. com/track/click?u=11112e09082f13dc2acea29b4\&id=796f599ad6\&e=f99c3 54c08 (eguneratze-data: 2021/09/29).

[28] RAVENTÓS PAÑELLA DANIEL. 2020. Espainiako Diputatuen Kongresuko ekonomia eta gizartea berreraikitzeko batzordean esku hartzea. Madril. https://www.congreso.es/busqueda-de-intervenciones?p_p_

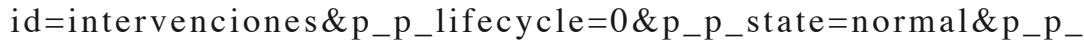
mode $=$ view\&_intervenciones_mode $=$ mostrarDetalle $\&$ intervenciones legislatura=XIV\&_intervenciones_id=2020062200039001200014133n0213 2190002130000652598 (eguneratze-data:2021/09/29).

[29] ARCARONS JORDI, RAVENTÓS DANIEL eta TORRENS LLUIS. 2017. Baldintzarik gabeko oinarrizko errenta. Arrazoizko eta bidezko finantzaketarako proposamena. Del Serbal, Bartzelona.

[30] ARCARONS JORDI, RAVENTÓS DANIEL eta TORRENS LLUIS. 2020. «Baldintzarik gabeko oinarrizko errenta unibertsala finantzatzeko eredu berriak». Red Renta Básica Elkartea. https://www.sinpermiso.info/textos/ nuevos-modelos-para-financiar-una-renta-basica-incondicional-y-universal (eguneratze-data: 2021/09/29).

[31] ARCARONS JORDI, RAVENTÓS DANIEL eta TORRENS LLUIS. 2020. «Esleipen publikoak finantzatzeko moduari buruzko datu berriak dituzten hurbilketak: etxebizitzari buruzko aipamen berezia». Red Renta Básica Elkartea. http://www .redrentabasica.org/rb/aproximaciones-con-nuevos-datos- 
sobre-como-se-podrian-financiar-asignaciones-publicas-mencion-especial-ala-viviend/ (eguneratze-data: 2021/09/29).

[32] KULTURAN LAN EGITEN DUEN JENDEA. 2020. Oinarrizko errenta unibertsal eta baldintzarik gabekoaren aldeko manifestua. https://nativa. cat/2020/04/gent-que-treballa-en-cultura-per-una-renda-basica-universal-iincondicional/ (eguneratze-data: 2021/09/29).

[33] AGINAGALDE ADRIÁN HUGO eta beste 43 egile. 2021. COVID19aren Liburu Zuria. https://covid19liburuzuria.eus/eu/ (eguneratzedata:2021/09/29).

[34] KOLEKTIBO FEMINISTAK. 2020. Guztiontzako baliabideak eta autonomia: oinarrizko errentaren aldeko manifestu feminista. https://rentabasicafeminista.home.blog/ (eguneratze-data:2021/09/29).

[35] AKADEMIAKO PROFESIONALAK. 2020. COVID-19 osteko Euskal Herriko ekonomia ekologikoaren aldeko manifestua. https://euskalherriapostcovid19.eus/ (eguneratze-data:2021/09/29).

[36] LGBTI KOLEKTIBOA. 2020. Oinarrizko errenta unibertsalaren aldeko manifestua. https://lgbtixrbu.wordpress.com/ (eguneratze-data:2021/09/29).

[37] ELÍAS ANGEL, RINCÓN LEIRE. (2016). «Oinarrizko errentaren zenbait ezaugarri». Hegoa Boletina, 48, 48-50. http://boletin.hegoa.ehu.es/mail/45 (eguneratze-data:2021/09/29).

[38] PLATAFORMA ACCIÓN 2030. «Oinarrizko errenta». Hamazazpigarren aldizkaria, Garapen Iraunkorrerako Helburuetarako Diziplinarteko Ikerketa. 1, https://plataforma2030.org/es/revista-diecisiete-2/advancedsearch/49 (eguneratze-data: 2021/09/29).

[39] BREGMAN RUTGER. 2017, Utopia errealistentzat. Oinarrizko errenta unibertsalaren alde, 15 orduko lan-astea eta mugarik gabeko mundua. Salamandra, Bartzelona.

[40] LAGO AZQUETA MARTIN. 2018. Oinarrizko errenta unibertsala. Konponbidea ala utopia? Digital Reasons, Madril.

[41] SOZIALISTAK GARA: PEDRO SÁNCHEZ SOZIALDEMOKRAZIA BERRI BATEN ALDE. 2017. Alderdi Sozialistaren Idazkaritza Nagusirako hauteskunde-programa. https://es.scribd.com/document/339841817/Poruna-nueva-socialdemocracia-el-proyecto-politico-de-Pedro-Sanchez (eguneratze-data: 2021/09/29).

[42] FRANTZISKO AITA SANTUA. 2020. Soñemos juntos. El camino a un mundo mejor. Plaza \&Janes Peguin Random. Bartzelona.

[43] EUROPEAN CITIZENS' INITIATIVE FOR UNCONDITIONAL BASIC INCOME. https://eci.ec.europa.eu/014/public/\#/screen/home (eguneratzedata: 2021/09/29).

[44] BALDINTZARIK GABEKO OINARRIZKO ERRENTAREN ALDEKO LEGEGINTZAKO HERRI-EKIMENA. https://rentabasica.eus/eu/nor/ (eguneratze-data: 2021/09/29). 